\title{
Review of Hydrogen Isotope Permeability Through Materials
}

\author{
S. A. Steward
}

\section{DO NOT MOROFILM COVER}

August 15, 1983

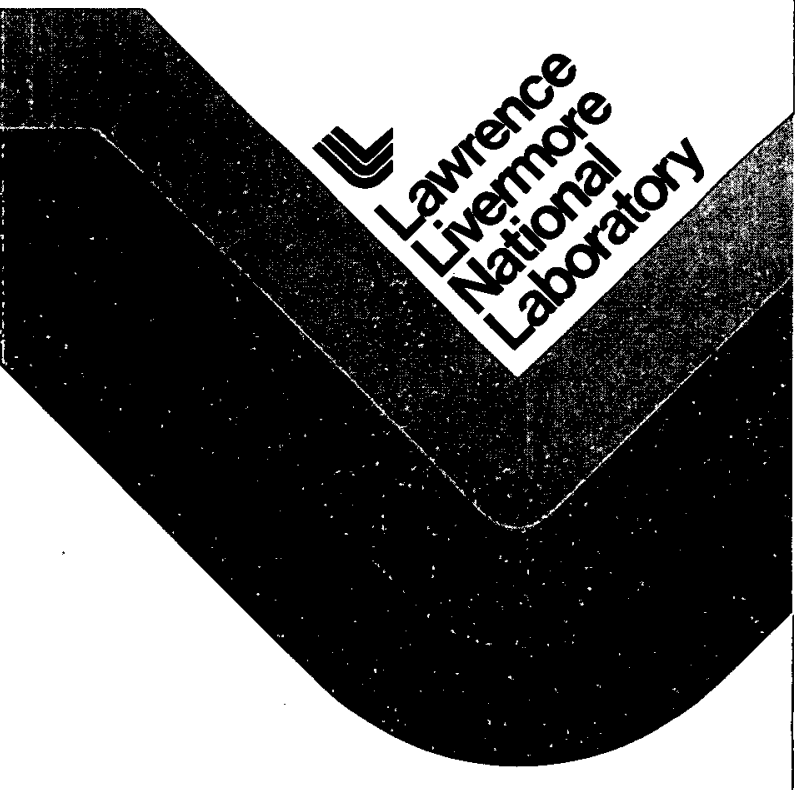




\section{DISCLAIMER}

This document was prepared as an account of work sponsored by an agency of the United States Government. Neither the United States Government nor the University of California nor any of their employees, makes any warranty, express or implied, or assumes any legal liability or responsibility for the accuracy, completeness, or usefulness of any information, apparatus, product, or process disclosed, or represents that its use would not infringe privately owned rights. Reference herein to any specific commercial products, process, or service by trade name, trademark, manufacturer, or otherwise, does not necessarily constitute or imply its endorsement, recommendation, or favoring by the United States Government or the University of California. The views and opinions of authors expressed herein do not necessarily state or reflect those of the United States Government thereof, and shall not be used for advertising or product endorsement purposes.

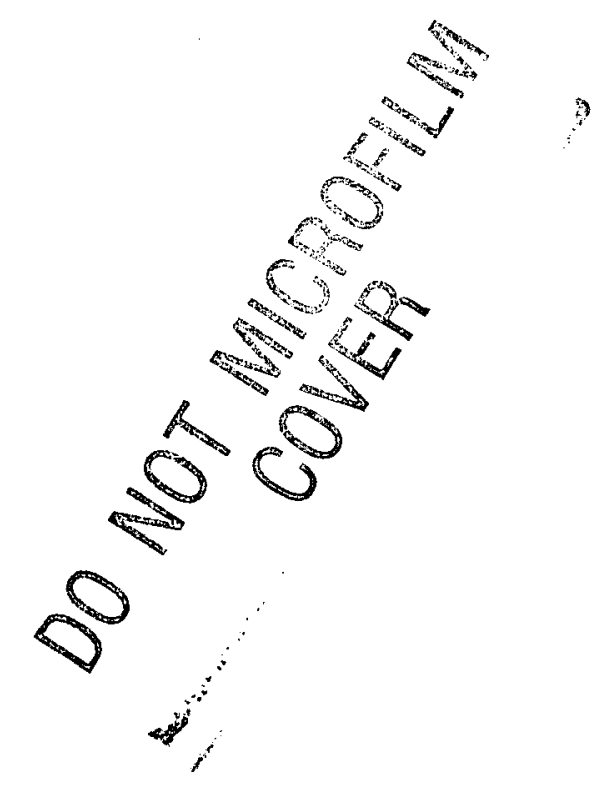

Work performed under the auspices of the U.S. Department of Energy by Lawrence Livermore National Laboratory under Contract W-7405-Eng-48. 


\section{DISCLAIMER}

This report was prepared as an account of work sponsored by an agency of the United States Government. Neither the United States Government nor any agency Thereof, nor any of their employees, makes any warranty, express or implied, or assumes any legal liability or responsibility for the accuracy, completeness, or usefulness of any information, apparatus, product, or process disclosed, or represents that its use would not infringe privately owned rights. Reference herein to any specific commercial product, process, or service by trade name, trademark, manufacturer, or otherwise does not necessarily constitute or imply its endorsement, recommendation, or favoring by the United States Government or any agency thereof. The views and opinions of authors expressed herein do not necessarily state or reflect those of the United States Government or any agency thereof. 


\section{DISCLAIMER}

Portions of this document may be illegible in electronic image products. Images are produced from the best available original document. 
UCRL-53441

Distribution Category UC-25

UCRL -53441

DE84. 007362

\title{
Review of Hydrogen Isotope Permeability Through Materials
}

\author{
S. A. Steward
}

Manuscript date: August 15, 1983

\section{DISCLAIMER}

This report was prepared as an account of work sponsored by an agency of the United States Government. Neither the United States Government nor any agency thereof, nor any of their employees, makes any warranty, express or implied, or assumes any legal liability or responsibility for the accuracy, completeness, or usefulness of any information, apparatus, product, or process disclosed, or represents that its use would not infringe privately owned rights. Reference herein to any specific commercial product, process, or service by trade name, trademark, manufacturer, or otherwise does not necessarily constitute or imply its endorsement, recommendation, or favoring by the United States Government or any agency thereof. The views and opinions of authors expressed herein do not necessarily state or reflect those of the United States Government or any agency thereof.

\section{LAWRENCE LIVERMORE NATIONAL LABORATORY University of California • Livermore, California $・ 94550$}

Available from: National Technical Information Service - U.S. Department of Commerce

5285 Port Royal Road $\bullet$ Springfield, VA 22161 per copy $\bullet$ (Microfiche 


\section{Contents}

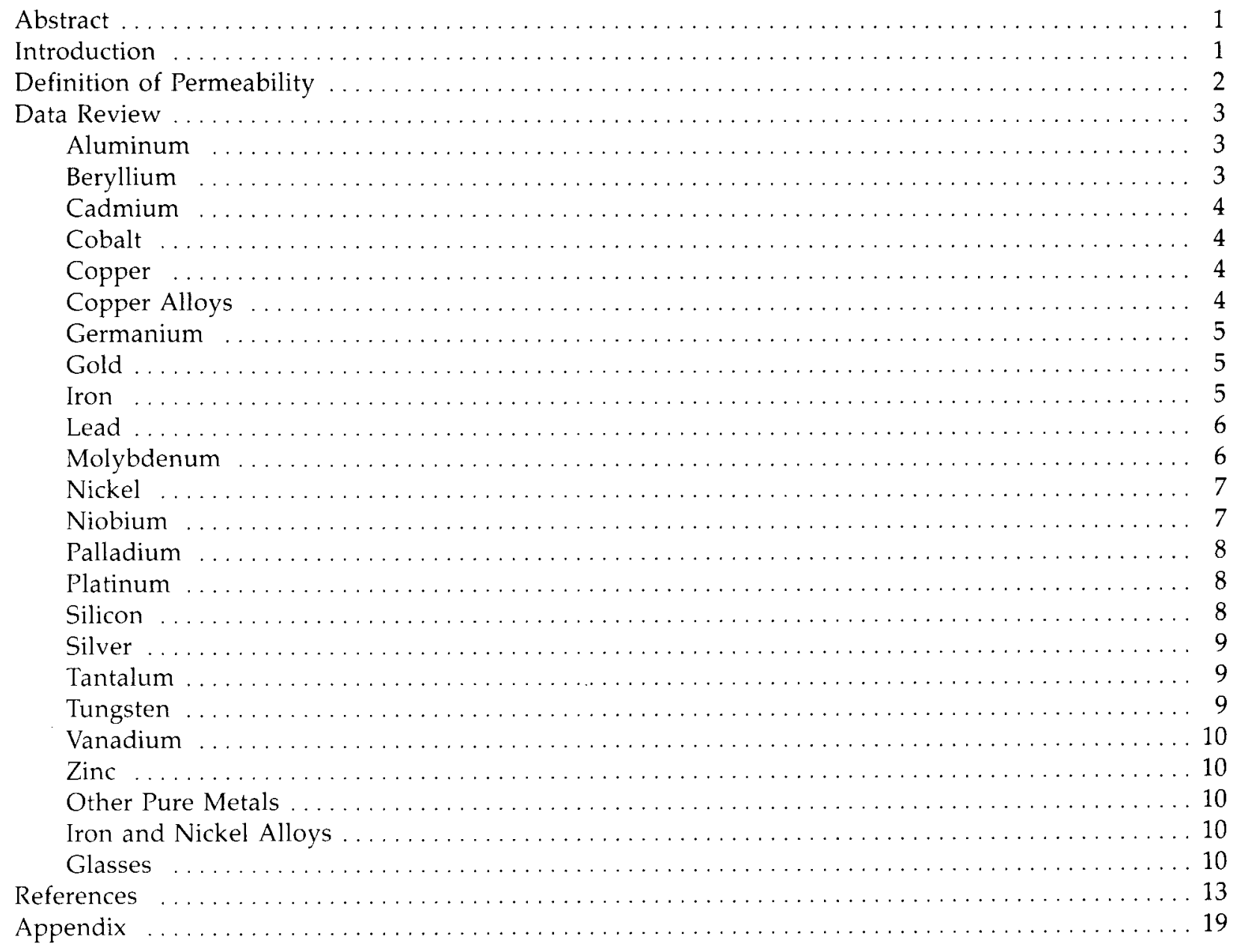




\title{
Review of Hydrogen \\ Isotope Permeability \\ Through Materials
}

\begin{abstract}
This report is the first part of a comprehensive summary of the literature on hydrogen isotope permeability through materials that do not readily form hydrides. While we mainly focus on pure metals with low permeabilities because of their importance to tritium containment, we also give data on higher-permeability materials such as iron, nickel, steels, and glasses.
\end{abstract}

\section{Introduction}

This paper is the first part of a comprehensive review and summary of the literature on hydrogen isotope permeability through materials. It is the first review of its kind. Hydrogen isotope permeability is important to many scientific fields, such as metallurgy, nuclear reactor design, and tritium processing.

Our own research has frequently required hydrogen permeability data through many materials, only to be frustrated by an absence of data or by obscure data. This review is a result of that frustration and need. Initially, we selected for review those materials that resist hydrogen penetration because we are interested in improving tritium containment. We have also included many higher-permeability materials, however, such as iron, steels, nickel and copper alloys, and glasses, because of their importance to tritium technology. Hydride-forming metals have been ignored because of their high hydrogen solubility at moderate pressures and their narrow dilute-solution or $\alpha$-phase regions.

Our intention is to continue to update this review and expand it to include ceramics; modified materials such as coated alloys, and organics. The updating and expansion will be done over several revisions of this report because of the enormity of the task.

The hydrogen permeation literature has several characteristics:

1. Most of it focuses on the higherpermeability materials mentioned above, because hydrogen permeates such materials relatively quickly, allowing ready measurement.

2. A corollary to point 1 is that most data are high-temperature, i.e., between $200^{\circ} \mathrm{C}$ and $1000^{\circ} \mathrm{C}$ or the melting point, an experimental approach that also facilitates easier measurement. Useful data at low temperatures do not exist, making extrapolation from high temperatures an error-prone affair.

3. Very few permeation data exist on tritium, probably because of its radioactivity and consequent restrictions on availability and use.

4. When permeability data are given as a function of temperature, the units vary widely, decreasing their utility. We have settled on a unit based on the SI system, which we hope will simplify calculations and make comparisons between materials easy.

5. In several reports the classic "time-lag" permeation method was used for measurement, but only the diffusion coefficient was calculated and reported; the directly measured permeability data were not given.

6. In many cases, diffusion and solubility data were available from different reports, sometimes from the same laboratory, but from different samples and techniques. We combined such data only when no other trustworthy permeability data were available, and still did so with great trepidation. 


\section{Definition of Permeability}

Steady-state permeability of gases through solids is defined by a variation of Fick's first law,

$I=-D \frac{\partial c}{\partial x}$

where $J$ is the flux of diffusing species, in units of $\mathrm{mol} / \mathrm{m}^{2} \cdot \mathrm{s}$, diffusing out of the material; $D$ is the diffusion coefficient in $\mathrm{m}^{2} / \mathrm{s}$; and $\partial c / \partial x$ is the concentration gradient across the solid. This solution is most easily envisioned in the semi-infinite plane sheet geometry of an isotropic solid.

Permeability becomes important in practical systems, when the surface concentrations of the gas are not known. In this case Henry's law,

$S_{\mathrm{H}}=\frac{C_{\text {gas }}}{P_{\text {gas }}}$

is used, where $S_{H}$ is a constant relating the vapor pressure of a nondissociative gas to its concentration in a liquid or solid at dilute concentration, i.e., the solution phase. The unit of $S_{\mathrm{H}}$ in Henry's law is $\mathrm{mol} / \mathrm{m}^{3} \cdot \mathrm{Pa} . \mathrm{C}_{\text {gas }}$ is the concentration of gas in the solvent in $\mathrm{mol} / \mathrm{m}^{3}$, and $P_{\text {gas }}$ is the pressure of the gas over the solvent in pascals. Since the inlet and outlet pressures of the gas can usually be measured, pressure is substituted for concentration into Fick's first law, via Henry's law.

The Henry's law constant is in fact our solubility constant $S$, which expresses concentration per unit of pressure. In the case of diatomic molecules, such as hydrogen, that dissociate prior to dissolution, a modification of Henry's law is required. This version is called Sieverts' law, in honor of an early scientist deeply involved in research on hydrogen solubility in metals. His work produced the observation that hydrogen solubility in metals was a function of the half-power of pressure, explained by dissociation of the molecule. Thus Sieverts' law,

$S=\frac{C_{\mathrm{H}}}{P_{\mathrm{H}_{2}}^{1 / 2}}$

may be used to convert Fick's first law to a usable form. The Sieverts' law constant $S$ is also called solubility and is in units of $\mathrm{mol} / \mathrm{m}^{3} \cdot \mathrm{Pa}^{1 / 2}$. The constant of Henry's and Sieverts' laws may often be given as inverts of the $S$ expressed above, but the version given in Eq. (3) serves our discussion more clearly. yields

Substitution of rearranged Eq. (3) into Eq. (1)

$I=-D S \frac{\partial P_{\mathrm{H}_{2}}^{1 / 2}}{\partial x} \simeq-D S \frac{\Delta P_{\mathrm{H}_{2}}^{1 / 2}}{\Delta x}$.

In this case, $\Delta P_{\mathrm{H}_{2}}^{1 / 2}$ is the square root of the pressure difference of the diffusing gas across a membrane, and $\Delta x$ is the thickness of the membrane. The negative sign in Eq. (4) represents the direction of diffusion and can be ignored in this discussion.

Equation (4) can be rearranged to correspond to the usual representation of the permeation data, where the total amount of gas that has permeated the membrane, $Q(\mathrm{~mol})$, is plotted as a function of time. Equation (4) then becomes

$Q=J A t=D S \frac{A}{\Delta x} \Delta P_{H_{2}}^{1 / 2} \cdot t$,

where $A$ is the slab area $\left(\mathrm{m}^{2}\right)$, and $t$ is the time (s) since reaching steady state.

The slope of this line $(d Q / d t)$, the steady-state flow rate, includes the constant DS, which is specific for a given membrane material. This product of $D$ and $S$, which we call $\Phi$ (sometimes called $K$ ), is defined as the permeability, here in the units $\mathrm{mol} / \mathrm{m} \cdot \mathrm{s} \cdot \mathrm{Pa}^{1 / 2}$. We have, by differentiating Eq. (5) and substituting $\Phi$ :

$\frac{d Q}{d t}=\Phi \frac{A}{\Delta x} \Delta P_{H_{2}}^{1 / 2}$

By knowing the steady-state flow rate, the area and thickness of the sample, and the hydrogen pressure difference across the sample, the permeability $\Phi$ may be calculated. A plot of $Q$ vs $t$ should be a straight line at steady state, and the slope is obviously $d Q / d t$, from which $\Phi$ may be easily calculated.

The permeability, like the diffusivity and solubility, is temperature-dependent and may be represented by an Arrhenius equation,

$\Phi=\Phi_{0} \exp \left(-E_{\Phi} / R T\right)$,

where

$\Phi_{0}=D_{0} S_{0}$, 
and

$$
E_{\Phi}=E_{D}+E_{S}
$$

The E's are activation energies for each process. In the following discussions, we have normalized $R$ so that the activation energies are independent of energy units and given in degrees Kelvin only. This process can be reversed, of course, by multiplying our energies $(\mathrm{K})$ by the value of $R$ in the desired energy units.

\section{Data Review}

The permeation data are listed by metal. Where there is a large body of data for a metal, the data are given in tabular form. Tabular data are listed in chronological order. Because permeation data have been published in many units, we have chosen a more rational, perhaps unfamiliar, SI-based unit, which is discussed above. For metals it is $\mathrm{mol} / \mathrm{m} \cdot \mathrm{s} \cdot \mathrm{Pa}^{1 / 2}$, and for nonmetals, $\mathrm{mol} / \mathrm{m} \cdot \mathrm{s} \cdot \mathrm{Pa}$. Once conversion is accomplished, data may be easily compared and various quantities calculated. Table A-1 in the appendix lists the factors to convert commonly encountered permeation units to $\mathrm{mol} / \mathrm{m} \cdot \mathrm{s} \cdot \mathrm{Pa}^{1 / 2}$. Tables A-2 and A-3 in the appendix give the selected "best" tritium and hydrogen permeabilities for quick reference.

\section{Aluminum}

There is a moderate-sized body of literature on the hydrogen/aluminum system. A large part of it, however, deals with diffusion and solubility. As Table 1 shows, of the five sets of permeability data, one (Boeschoeten et al., 1960) is of little use, due to large scatter in the results. The other four divide into two pairs of comparable results. The results of Eichenauer et al. (1961) and Cochran (1961) have similar preexponentials, but widely varying activation energies. The results of Eichenauer and Pebler (1957) and Ihle et al. (1976) agree quite well, particularly when the former are divided by the square root of the mass ratios (1.7). Ihle et al. combined their higher-temperature data $(<400 \mathrm{~K})$ with those of Cochran and compared the combined data with the data of Eichenhauer and Pebler. This combination shows the results to be more similar than are equations fit to each set of data.

At present we take the results of Ihle et al. as the best usable temperature-dependent permeability:

$$
\begin{aligned}
\Phi\left(\mathrm{T}_{2} / \mathrm{Al}\right)= & 5.8 \times 10^{-5} \\
& \times \exp (-14,800 / \mathrm{T}) \mathrm{mol} / \mathrm{m} \cdot \mathrm{s} \cdot \mathrm{Pa}^{1 / 2} .
\end{aligned}
$$

The above equation seems reliable at this point. However, surface conditions of aluminum are likely to strongly affect hydrogen permeability, particularly at lower temperatures, as Boeschoten et al. saw. A more thorough understanding of the effect of the surface condition of aluminum on hydrogen permeability is needed.

\section{Beryllium}

Jones and Gibson (1967) reported the only known results of tritium permeability, diffusivity, or solubility in beryllium. They loaded an arc-cast beryllium sample with tritium at several temperatures, then outgassed at higher temperatures. The

\begin{tabular}{|c|c|c|c|c|c|}
\hline $\begin{array}{c}\Phi_{0} \\
\left(10^{5} \mathrm{~mol} / \mathrm{m} \cdot \mathrm{s} \cdot \mathrm{Pa}^{1 / 2}\right)\end{array}$ & $\begin{array}{r}E_{\Phi} \\
(\mathrm{K})\end{array}$ & $\begin{array}{l}\text { Temperature range } \\
\qquad(\mathrm{K})\end{array}$ & $\begin{array}{l}\text { Pressure } \\
\text { (kPa) }\end{array}$ & Gas & Reference \\
\hline 18 & 15,250 & $740-860$ & 80 & $\mathrm{H}_{2}$ & Eichenauer and Pebler (1957) \\
\hline- & 30,000 & $630-670$ & - & $\mathrm{H}_{2}, \mathrm{H}_{2} \mathrm{O}$ & Boeschoten et al. (1960) \\
\hline 0.38 & 18,900 & $630-870$ & $25-100$ & $\mathrm{H}_{2}$ & Eichenauer et al. (1961) \\
\hline 0.45 & 12,360 & $670-870$ & 100 & $\mathrm{H}_{2}$ & Cochran (1961) \\
\hline 5.8 & 14,800 & $420-520$ & 20 & $\mathrm{~T}_{2}$ & Ihle et al. (1976) \\
\hline
\end{tabular}
temperature-dependent permeability obtained

Table 1. Aluminum permeability data. 
from the product of this measured diffusivity and solubility is the following, in our units:

$$
\begin{aligned}
\Phi\left(\mathrm{T}_{2} / \mathrm{Be}\right)= & 5.8 \times 10^{-14} \\
& \times \exp (-2220 / \mathrm{T}) \mathrm{mol} / \mathrm{m} \cdot \mathrm{s} \cdot \mathrm{Pa}^{1 / 2}
\end{aligned}
$$

The activation energy is small, indicating very little change in permeability with temperature. We believe this result may be incorrect. Our experience with beryllium indicates that the permeability is lower, although our current samples were formed from sintered beryllium powder, which contained $8 \mathrm{wt} \%$ oxygen. We are attempting other experiments with disks of singlecrystal beryllium.

More recently, Al'tovskiy et al. (1981) reported hydrogen permeability through sintered tubes and membranes. The presentation of their data is inconsistent and confusing. We have fitted their beryllium "tube" data (labeled in their report as Be1) to the following equation:

$$
\begin{aligned}
\Phi\left(\mathrm{H}_{2} / \mathrm{Be}\right)= & 3.5 \times 10^{-7} \\
& \times \exp (-10,600 / \mathrm{T}) \mathrm{mol} / \mathrm{m} \cdot \mathrm{s} \cdot \mathrm{Pa}^{1 / 2}
\end{aligned}
$$

This activation energy is similar to the value they mention. Fits to other data in the article produce considerably different results. The activation energies vary from 3000 to $20,000 \mathrm{~K}$, and the preexponentials vary from $10^{-2}$ to $10^{-11}$ $\mathrm{mol} / \mathrm{m} \cdot \mathrm{s} \cdot \mathrm{Pa}^{1 / 2}$. In our analysis, we have assumed that their permeation unit of $\mathrm{cm}^{3}$ (STP) $\mathrm{mm} / \mathrm{cm}^{2} \cdot \mathrm{h}$ included all of the usual variables except pressure, and were, therefore, permeabilities at the given pressure. Al'tovskiy et al. did show a definite proportional dependence of permeability on grain size, which may relate to differences between the work of Jones and Gibson and our own. The only common thread in these results is that all of the permeabilities of Al'tovskiy ot al. were considerably higher than those of Jones and Gibson. The numerous inconsistencies make this work, as presented, very unreliable.

Fidelle et al. (1967) reported the permeability of hydrogen in beryllium at room temperature only. It is:

$\Phi\left(\mathrm{H}_{2} / \mathrm{Be}, 20^{\circ} \mathrm{C}\right)=2.5 \times 10^{-16} \mathrm{~mol} / \mathrm{m} \cdot \mathrm{s} \cdot \mathrm{Pa}^{1 / 2}$

The data from these three sources indicate a real need for a more thorough study of hydrogen permeability through beryllium.

\section{Cadmium}

As with beryllium, Fidelle ct al. (1967) give a room-temperature permeability of hydrogen through cadmium of

$$
\Phi\left(\mathrm{H}_{2} / \mathrm{Cd}, 20^{\circ} \mathrm{C}\right)=4.1 \times 10^{-18} \mathrm{~mol} / \mathrm{m} \cdot \mathrm{s} \cdot \mathrm{Pa}^{1 / 2}
$$

This is the only result of which we are aware.

\section{Cobalt}

The sole measurement of hydrogen permeability through cobalt was reported by Caskey of al. in 1974. They found different permeabilities for the $\alpha$ and $\epsilon$ phases of cobalt. Their results with deuterium at $0.5 \mathrm{MPa}$, between 470 and $820 \mathrm{~K}$ are:

$$
\begin{aligned}
& \Phi\left(\mathrm{D}_{2} / \epsilon-\mathrm{Co},<670 \mathrm{~K}\right)= 6.3 \times 10^{-9} \\
& \times \exp (-6850 / \mathrm{T}) \mathrm{mol} / \mathrm{m} \cdot \mathrm{s} \cdot \mathrm{Pa}^{1 / 2} \\
& \Phi\left(\mathrm{D}_{2} / \alpha-\mathrm{Co}_{2}>670 \mathrm{~K}\right)=3.8 \times 10^{-8} \\
& \times \exp (-7750 / \mathrm{T}) \mathrm{mol} / \mathrm{m} \cdot \mathrm{s} \cdot \mathrm{Pa}^{1 / 2}
\end{aligned}
$$

\section{Copper}

There have been numerous measurements of hydrogen and deuterium permeability through copper (Table 2). All measurements, except those of Eichenauer and his colleagues, were made using the membrane technique. Eichenauer and colleagues measured diffusivity and solubility separately. Relatively pure copper was used in all experiments. The values of Perkins and Begeal (1972) and Gorman and Nardella (1962) probably represent the best values for hydrogen permeability. These numbers should be good over a wide range of temperature $(400-900 \mathrm{~K}$ ) and pressure $(0.1-200 \mathrm{kPa})$.

\section{Copper Alloys}

Begeal (1978) has measured twenty hydrogen and deuterium permeabilities in several copper alloys, including aluminum, silicon, and phosphate bronzes, and copper-beryllium. Several goldcopper brazing alloys were also examined. 
Table 2. Copper permeability data.

\begin{tabular}{ccclll}
\hline $\begin{array}{c}\Phi_{0} \\
\left(10^{7} \mathrm{~mol} / \mathrm{m} \cdot \mathrm{s} \cdot \mathrm{Pa}^{1 / 2}\right)\end{array}$ & $\begin{array}{c}E_{\Phi} \\
(\mathrm{K})\end{array}$ & $\begin{array}{c}\text { Temperature range } \\
(\mathrm{K})\end{array}$ & $\begin{array}{c}\text { Pressure } \\
(\mathrm{kPa})\end{array}$ & Gas & \multicolumn{1}{c}{ Reference } \\
\hline 0.864 & 8240 & $500-730$ & 0.017 & $\mathrm{H}_{2}$ & \multicolumn{1}{c}{ Smithells and Ransley (1935) } \\
8.07 & 9950 & $420-600$ & 0.1 & $\mathrm{H}_{2}$ & Braaten and Clark (1936) \\
4.1 & 8960 & $530-920$ & - & $\mathrm{H}_{2}$ & Eichenauer and Pebler (1957) \\
0.0825 & 6290 & $620-770$ & 0.15 and 0.2 & $\mathrm{H}_{2}$ & Rudd et al. (1961) \\
5.86 & 9100 & $620-970$ & 0.1 & $\mathrm{H}_{2}$ & Gorman and Nardella (1962) \\
52.0 & 9470 & $700-900$ & $0.013-0.1$ & $\mathrm{H}_{2}$ & Eichenauer et al. (1965) \\
32.7 & 9630 & $700-900$ & $0.013-0.1$ & $\mathrm{D}_{2}$ & Eichenauer et al. (1965) \\
8.42 & 9290 & $470-710$ & $0.00013-0.13$ & $\mathrm{H}_{2}$ & Perkins and Begeal (1972) \\
0.58 & 8620 & $375-750$ & 0.1 and 0.5 & $\mathrm{D}_{2}$ & Caskey et al. (1976) \\
8.4 & 9320 & $470-700$ & $0.00013-0.13$ & $\mathrm{H}_{2}$ & Begeal (1978) \\
\hline
\end{tabular}

Outside of the high-gold-content alloys, the preexponentials were in the range $1-9 \times 10^{-7}$ $\mathrm{mol} / \mathrm{m} \cdot \mathrm{s} \cdot \mathrm{Pa}^{1 / 2}$, and the activation energies are near $-10,000 \mathrm{~K}$. Temperatures were between 600 and $900 \mathrm{~K}$ and pressures in the $10-300 \mathrm{kPa}$ range. See Begeal (1978) for exact values.

Caskey and Derrick (1977) measured the hydrogen permeabilities through several alphabrasses with up to $35 \mathrm{wt} \%$ zinc. There was no consistency in the changes in the preexponential or activation energies with increasing zinc content. A graph of the permeabilities vs temperature indicated that the least squares permeabilities generally decreased with increasing zinc content.

\section{Germanium}

The only hydrogen permeability data for germanium were given by Van Wieringen and Warmoltz (1956). Their permeation equation, converted to our units, is

$$
\begin{aligned}
\Phi\left(\mathrm{H}_{2} / \mathrm{Ge}\right)= & 1.2 \times 10^{-5} \\
& \times \exp (-24,000 / \mathrm{T}) \mathrm{mol} / \mathrm{m}: \mathrm{s} \cdot \mathrm{Pa}^{1 / 2} .
\end{aligned}
$$

Their measurements were taken on a hollow single crystal between 1040 and $1200 \mathrm{~K}$ at $1 \mathrm{~atm}$ hydrogen pressure, using a modified time-lag method.

\section{Gold}

There are two measurements of hydrogen permeation through gold. The results of Caskey and Derrick (1976) and Begeal (1978) are very sim- ilar. They both used deuterium and the time-lag method, and covered comparable pressure and temperature ranges. Caskey and Derrick's results are given by

$$
\begin{aligned}
\Phi\left(\mathrm{D}_{2} / \mathrm{Au}\right)= & 3.1 \times 10^{-6} \\
& \times \exp (-14,800 / \mathrm{T}) \mathrm{mol} / \mathrm{m} \cdot \mathrm{s} \cdot \mathrm{Pa}^{1 / 2},
\end{aligned}
$$

and Begeal's are given by

$$
\begin{aligned}
\Phi\left(\mathrm{D}_{2} / \mathrm{Au}\right)= & 1.14 \times 10^{-6} \\
& \times \exp (-13,800 / \mathrm{T}) \mathrm{mol} / \mathrm{m} \cdot \mathrm{s} \cdot \mathrm{Pa}^{1 / 2}
\end{aligned}
$$

Either equation could be chosen for calculations.

\section{Iron}

Measurements of hydrogen permeability in iron are numerous. We found almost 20 references. Thirteen of these were reviewed by Gonzalez (1967). Only the most recent reports, including Gonzalez's review, are enumerated here (Table 3). The results are remarkably similar. The value given by Gonzalez,

$$
\begin{aligned}
\Phi\left(\mathrm{H}_{2} / \mathrm{Fe}\right)= & 4.1 \times 10^{-8} \\
& \times \exp (-4200 / \mathrm{T}) \mathrm{mol} / \mathrm{m} \cdot \mathrm{s} \cdot \mathrm{Pa}^{1 / 2},
\end{aligned}
$$

is likely the most suitable for calculation, because it represents an average of many measurements. Small impurities and grain size seemingly have no significant effect on the permeability of hydrogen through iron. 
Table 3. Iron permeability data.

\begin{tabular}{cccccl}
\hline $\begin{array}{c}\Phi_{0} \\
\left(10^{8} \mathrm{~mol} / \mathrm{m} \cdot \mathrm{s} \cdot \mathrm{Pa}^{1 / 2}\right)\end{array}$ & $\begin{array}{c}E_{\Phi} \\
(\mathrm{K})\end{array}$ & $\begin{array}{c}\text { Temperature range } \\
(\mathrm{K})\end{array}$ & $\begin{array}{c}\text { Pressure } \\
(\mathbf{k P a})\end{array}$ & Gas & \multicolumn{1}{c}{ Reference } \\
\hline 4.1 & 4200 & $>375$ & up to $10 \mathrm{MPa}$ & $\mathrm{H}_{2}$ & Gonzalez (1967) \\
3.58 & 4100 & $330-770$ & $10-1000$ & $\mathrm{H}_{2}$ & Nelson and Stein (1973) \\
19.5 & 4700 & $260-700$ & $20-500$ & $\mathrm{H}_{2}$ & Louthan et al. (1975) \\
8.13 & 4700 & $260-700$ & $20-500$ & $\mathrm{~T}_{2}$ & Louthan et al. (1975) \\
8.63 & 4300 & $480-875$ & 10 & $\mathrm{H}_{2}$ & Wagner and Sizmann (1975) \\
6.78 & 4300 & $275-335$ & $1-100$ & $\mathrm{H}_{2}$ & Kumnick and Johnson (1975) \\
4.98 & 4217 & $282-346$ & $1-100$ & $\mathrm{H}_{2}$ & Kumnick and Johnson (1977) \\
6.60 & 4290 & $322-783$ & $0.4-60$ & $\mathrm{H}_{2}$ & Quick and Johnson (1978) \\
\hline
\end{tabular}

\section{Lead}

We could only find one measurement of hydrogen permeation through lead: the early work of Deming and Hendricks (1923). They give three data points, at 530,540 , and $555 \mathrm{~K}$. Our fit to this equation is

$$
\begin{aligned}
\Phi\left(\mathrm{H}_{2} / \mathrm{Pb}\right)= & 0.121 \\
& \times \exp (-11,900 / \mathrm{T}) \mathrm{mol} / \mathrm{m} \cdot \mathrm{s} \cdot \mathrm{Pa}^{1 / 2} .
\end{aligned}
$$

At $550 \mathrm{~K}$ this gives a permeability of $4 \times$ $10^{-11} \mathrm{~mol} / \mathrm{m} \cdot \mathrm{s} \cdot \mathrm{Pa}^{1 / 2}$. We feel this is too high compared with other low-permeability materials, and therefore we would not use the above equation.

\section{Molybdenum}

Many authors have measured the permeability of hydrogen through molybdenum. No tritium data exist. Table 4 lists ten references. In addition to the amount of data available, the similarity of the results is remarkable. A review by Chandler and Walter (1968) gives an average value of permeability, from several works, of:

$\Phi\left(\mathrm{H}_{2} / \mathrm{Mo}\right)=2.3 \times 10^{-7}$

$$
\times \exp (-9710 / \mathrm{T}) \mathrm{mol} / \mathrm{m} \cdot \mathrm{s} \cdot \mathrm{Pa}^{1 / 2}
$$

The three later reports do not contradict this

\begin{tabular}{|c|c|c|c|c|c|}
\hline $\begin{array}{c}\Phi_{0} \\
\left(10^{7} \mathrm{~mol} / \mathrm{m} \cdot \mathrm{s} \cdot \mathrm{Pa}^{1 / 2}\right)\end{array}$ & $\begin{array}{c}E_{\Phi} \\
(\mathrm{K})\end{array}$ & $\begin{array}{c}\text { Temperature range } \\
\text { (K) }\end{array}$ & $\begin{array}{l}\text { Pressure } \\
\text { (kPa) }\end{array}$ & Gas & Reference \\
\hline 3.59 & 10,100 & $820-1670$ & $0.1-10$ & $\mathrm{H}_{2}$ & Smithells and Ransley (1935) \\
\hline 22.7 & 12,280 & $850-1250$ & 100 & $\mathbf{H}_{2}$ & Hill (1960) \\
\hline 1.65 & 9,150 & $900-1500$ & 100 & $\mathrm{H}_{2}$ & Huffine and Williams (1960) \\
\hline 4.0 & 11,000 & $900-1200$ & 100 & $\mathrm{H}_{2}$ & Steigerwald (1963) \\
\hline 2.4 & 9,660 & 520 and 620 & 85 & $\mathrm{H}_{2}$ & Jones et al. (1966) \\
\hline 3.62 & 10,800 & $1100-2000$ & 0.3 and 30 & $\mathrm{H}_{2}$ & Frauenfelder (1968) \\
\hline 2.33 & 9,710 & $500-1700$ & - & $\mathrm{H}_{2}$ & Chandler and Walter (1968) \\
\hline $1.4^{\mathrm{a}}$ & 9,300 & $679-1270$ & $0.1-30$ & $\mathrm{H}_{2}$ & Zakharov et al. (1973) \\
\hline $\begin{array}{c}3.6 \\
5.3\end{array}$ & 8,760 & $540-910$ & $0.1-300$ & $\mathrm{H}_{2}$ & Gutherie et al. (1974) \\
\hline 3.22 & 9,980 & $523-730$ & 100 & $\mathrm{H}_{2}$ & Caskey et al. (1975) \\
\hline
\end{tabular}
"best fit" to any significant degree. The various

Table 4. Molybdenum permeability data.

a Single-crystal molybdenum.

b Polycrystalline molybdenum. 
results span wide ranges of temperature (500$1700 \mathrm{~K})$ and pressure $(0.1-300 \mathrm{kPa})$. With one exception, the samples were polycrystalline, and the "time-lag" method was used with tubes or membranes.

\section{Nickel}

As with iron, there has been considerable study of hydrogen permeation through nickel (Table 5). The many results are comparable, except for those of Eichenauer et al. (1965) and Tanabe et al. (1977). The permeabilities given by either Ebisuzaki et al. (1967), Robertson (1973), or Louthan et al. (1975, 1976) could be used in calculations.

\section{Niobium}

Clean niobium reacts readily and exothermically with hydrogen. Having such a negative heat of solution, it is different from the endothermic resistant metals, whose hydrogen solubility increases with temperature. Diffusivity and solubility are oppositely influenced by temperature, as is the case for palladium and the other two Group VB metals, vanadium and tantalum. There are no direct measurements of hydrogen permeation through niobium, so we multiply reliable diffusivity and solubility measurements together. Völkl and Alefeld (1975) summarize six measurements of diffusivity over the temperature range -50 to $600^{\circ} \mathrm{C}$. The data are self-consistent, with an average value of:

$D=5.0 \times 10^{-8} \exp (-1230 / T) \mathrm{m}^{2} / \mathrm{s}$.
Converting the solubility data of Veleckis and Edwards (1969) to our units, we have the $\alpha$-phase hydrogen solubility in niobium:

$S\left(\mathrm{H}_{2} / \mathrm{Nb}\right)=0.126 \exp (4240 / \mathrm{T}) \mathrm{mol} / \mathrm{m}^{3} \cdot \mathrm{Pa}^{1 / 2}$.

Steward (1975) reports both hydrogen and deuterium solubilities in niobium. His solubility for hydrogen, again translated into the same units, is similar to that of Veleckis and Edwards and is

$$
S\left(\mathrm{H}_{2} / \mathrm{Nb}\right)=0.127 \exp (5550 / T) \mathrm{mol} / \mathrm{m}^{3} \cdot \mathrm{Pa}^{1 / 2}
$$

Calculation of permeation from combining these two results with Völkl and Alefeld's gives

$$
\begin{aligned}
\Phi\left(\mathrm{H}_{2} / \mathrm{Nb}\right)=6.3 & \times 10^{-9} \\
& \times \exp (3010 / \mathrm{T}) \mathrm{mol} / \mathrm{m} \cdot \mathrm{s} \cdot \mathrm{Pa}^{1 / 2}
\end{aligned}
$$

for the results of Veleckis and Edwards, and

$$
\begin{aligned}
\Phi\left(\mathrm{H}_{2} / \mathrm{Nb}\right)=6.3 & \times 10^{-9} \\
& \times \exp (4270 / \mathrm{T}) \mathrm{mol} / \mathrm{m} \cdot \mathrm{s} \cdot \mathrm{Pa}^{1 / 2}
\end{aligned}
$$

for the results of Steward. The results are similar, and either can be used for calculations. Caution should be exercised in using these numbers at high hydrogen pressures or low temperatures, where hydride formation or nonideality may occur. Pressures below $1 \times 10^{4} \mathrm{~Pa}$ and temperatures above $400^{\circ} \mathrm{C}$ should be observed.

Table 5. Nickel permeability data.

\begin{tabular}{ccclll}
\hline $\begin{array}{c}\Phi_{0} \\
\left(10^{7} \mathrm{~mol} / \mathrm{m} \cdot \mathrm{s} \cdot \mathrm{Pa}^{1 / 2}\right)\end{array}$ & $\begin{array}{c}E_{\Phi} \\
(\mathrm{K})\end{array}$ & $\begin{array}{c}\text { Temperature range } \\
(\mathrm{K})\end{array}$ & $\begin{array}{c}\text { Pressure } \\
(\mathrm{kPa})\end{array}$ & Gas & \multicolumn{1}{c}{ Reference } \\
\hline 30.0 & 6670 & $650-873$ & 100 & $\mathrm{H}_{2}$ & Ham (1933) \\
4.65 & 6640 & $675-1125$ & 100 & $\mathrm{H}_{2}$ & Gorman and Nardella (1962) \\
6.73 & 4770 & $650-920$ & $10-100$ & $\mathrm{H}_{2}$ & Eichenauer et al. (1965) \\
4.76 & 4600 & $650-920$ & $10-100$ & $\mathrm{D}_{2}$ & Eichenauer et al. (1965) \\
4.06 & 6623 & $480-690$ & 100 & $\mathrm{H}_{2}$ & Ebisuzaki et al. (1967) \\
3.22 & 6590 & $300-775$ & $1-100$ & $\mathrm{H}_{2}$ & Robertson (1973) \\
3.9 & 6660 & $300-550$ & $40-400$ & $\mathrm{H}_{2}$ & Louthan et al. (1975) \\
1.54 & 6500 & $300-650$ & $0.1-30$ & $\mathrm{~T}_{2}$ & Louthan and Derrick (1976) \\
10.4 & 8300 & $600-900$ & $5-10$ & $\mathrm{H}_{2}$ & Louthan and Derrick (1976) \\
3.33 & 7350 & $600-900$ & $5-10$ & $\mathrm{D}_{2}$ & Tanabe et al. (1977) \\
2.38 & 6290 & $600-800$ & $<12 \mathrm{MPa}$ & $\mathrm{H}_{2}$ & Gala et al. (1981)
\end{tabular}




\section{Palladium}

The palladium-hydrogen system is probably the most studied of any metal-hydrogen system. At least 25 measurements of the diffusivity are available. The more reliable results are quite consistent. The palladium-hydrogen phase diagram and thermodynamic properties have also been heavily studied, as evidenced by Lewis's (1967) review book. Despite this wealth of data, we know of only two permeability results. The first report was by Koffler et al. (1969). In our units, they gave the permeability as

$$
\begin{aligned}
\Phi\left(\mathrm{H}_{2} / \mathrm{Pd}\right)=2.20 & \times 10^{-7} \\
& \times \exp (-1885 / \mathrm{T}) \mathrm{mol} / \mathrm{m} \cdot \mathrm{s} \cdot \mathrm{Pa}^{1 / 2}
\end{aligned}
$$

from 0.04 to $7 \mathrm{~Pa}$ and from 300 to $709 \mathrm{~K}$.

Balovnev (1974) erroneously compared his later results to Koffler et al.'s, but they are nonetheless similar. His value of permeability is:

$$
\begin{aligned}
\Phi\left(\mathrm{H}_{2} / \mathrm{Pd}\right)= & 8.11 \times 10^{-7} \\
& \times \exp (-1860 / \mathrm{T}) \mathrm{mol} / \mathrm{m} \cdot \mathrm{s} \cdot \mathrm{Pa}^{1 / 2} .
\end{aligned}
$$

His results covered the ranges $3 \times 10^{-5}$ to $7 \times$ $10^{-2} \mathrm{~Pa}$, and 370 to $900 \mathrm{~K}$. We have some preference for the work of Koffler et al. because they seemed to do a more reliable data analysis and comparison.

\section{Platinum}

There are surprisingly few data for hydrogen permeability through platinum. We could find only four references (Table 6). The results of Ebisuzaki et al. (1968) and Katsuta and McLellan (1979) seem the most reliable in that they are similar and the samples were of very high purity.
The reported permeabilities of Katsuta and McLellan are half the value of the product of the diffusivity and solubility fitted to their data. This product, including both $\Phi_{0}$ and $E_{\Phi}$, corresponds quite well to the results of Ebisuzaki ct al. The results of Ham (1933) approximate the others and may differ because of the limited vacuums and materials purity available 50 years ago. The results of Ebisuzaki ef al. would be a good choice for calculations. Combined with Katsuta and McLellan's results, Ebisuzaki ct al.'s permeability is useful over a wide range of temperature (500-1200 K) and pressure $\left(10^{-8}-100 \mathrm{kPa}\right)$.

Solubility data in a super-pure platinum single crystal were measured by Yei and McLellan (1979) but were greater by about one order of magnitude over a similar temperature range than previous work from the same laboratory (Katsuta and McLellan).

\section{Silicon}

Van Wieringen and Warmoltz (1956) provide the only hydrogen permeation data through pure silicon and germanium, as mentioned earlier. The measurements were with single-crystal silicon between 1240 and $1485 \mathrm{~K}$ at $1 \mathrm{~atm}$ hydrogen. They also measured the helium permeabilities in these semiconductors. A least-squares fit of their permeability data gives the following equation, in our units and allowed accuracy:

$$
\Phi\left(\mathrm{H}_{2} / \mathrm{Si}\right)=1.4 \times 10^{-5}
$$

$$
\times \exp (-27,000 / \mathrm{T}) \mathrm{mol} / \mathrm{m} \cdot \mathrm{s} \cdot \mathrm{Pa}^{1 / 2}
$$

Ichimiya and Furuichi (1968) measured tritium diffusivity between 670 and $770 \mathrm{~K}$ and

Table 6. Platinum permeability data.

\begin{tabular}{ccccll}
\hline $\begin{array}{c}\Phi_{0} \\
\left(10^{7} \mathrm{~mol} / \mathrm{m} \cdot \mathrm{s} \cdot \mathrm{Pa}^{1 / 2}\right)\end{array}$ & $\begin{array}{c}E_{\Phi} \\
(\mathrm{K})\end{array}$ & $\begin{array}{c}\text { Temperature range } \\
(\mathrm{K})\end{array}$ & $\begin{array}{c}\text { Pressure } \\
(\mathrm{kPa})\end{array}$ & Gas & \multicolumn{1}{c}{ Reference } \\
\hline 8.1 & 9400 & $705-827$ & 100 & $\mathrm{H}_{2}$ & Ham (1933) \\
1.2 & 8500 & $540-900$ & 70 & $\mathrm{H}_{2}$ & Ebisuzaki et al. (1968) \\
$0.58 \pm 0.15$ & 7700 & $830-1210$ & $10^{-6}-10^{-8}$ & $\mathrm{H}_{2}$ & Katsuta and McLellan (1979) \\
1 & 8300 & $830-1210$ & $10^{-6}-10^{-8}$ & $\mathrm{H}_{2}$ & Katsuta and McLellan (1979) \\
0.165 & 6910 & $725-875$ & $2 \times 10^{5}$ & $\mathrm{H}_{2}$ & Harvie et al. (1980) \\
\hline
\end{tabular}


solubility between 1200 and $1500 \mathrm{~K}$ in borondoped (p-type) silicon, using the absorption outgassing method. The calculated permeability from their combined diffusivity and solubility is

$$
\begin{aligned}
\Phi\left(\mathrm{H}_{2} / \mathrm{Si}[\mathrm{B}]\right) & =1.8 \times 10^{-9} \\
& \times \exp (-24,000 / \mathrm{T}) \mathrm{mol} / \mathrm{m} \cdot \mathrm{s} \cdot \mathrm{Pa}^{1 / 2}
\end{aligned}
$$

The two results differ by about 1000 in the temperature range measured. The low results of Ichimiya and Furuichi may be due to the boron doping or oxides. Extrapolating either result to low temperatures is a mistake, even though the two results agree well at room temperature.

\section{Silver}

Zvedin and Belyakov (1967) reported the only direct permeability data for hydrogen through silver. Unfortunately, the data are presented only graphically. A calculation of the slope and intercept of their data yields the following results, in our standard units:

$$
\begin{aligned}
\Phi\left(\mathrm{H}_{2} / \mathrm{Ag}\right)= & 3 \times 10^{-8} \\
& \times \exp (-7350 / \mathrm{T}) \mathrm{mol} / \mathrm{m} \cdot \mathrm{s} \cdot \mathrm{Pa}^{1 / 2}
\end{aligned}
$$

This equation does not correspond to a permeation constant at $930 \mathrm{~K}\left(660^{\circ} \mathrm{C}\right)$ given in a table in the same paper, thus lending suspicion to their results.

Katsuta and McLellan (1979) measured the diffusivity of hydrogen in silver with a membrane permeability apparatus. They did not report, though, the permeability results they obtained. By combining these diffusivity results with solubility results reported earlier on different samples by McLellan (1973), who obtained them by another technique, we have perhaps a more reliable permeability value:

$$
\begin{aligned}
\Phi\left(\mathrm{H}_{2} / \mathrm{Ag}\right)= & 2.21 \times 10^{-7} \\
& \times \exp (-10,440 / \mathrm{T}) \mathrm{mol} / \mathrm{m} \cdot \mathrm{s} \cdot \mathrm{Pa}^{1 / 2}
\end{aligned}
$$

We have some faith in this value because it agrees within a factor of 5 with our own measurement of tritium permeation through silver at $100^{\circ} \mathrm{C}$.

\section{Tantalum}

As with the other VB metals, there are no reported measurements of hydrogen permeation through tantalum. As we did for those metals, we combine the solubility data of Veleckis and Edwards (1969) with the selected data of Völkl and Alefeld (1975) to obtain the permeability:

$$
\begin{aligned}
S\left(\mathrm{H}_{2} / \mathrm{Ta}\right)= & 0.132 \exp (4050 / \mathrm{T}) \mathrm{mol} / \mathrm{m}^{3} \cdot \mathrm{Pa}^{1 / 2} \\
D\left(\mathrm{H}_{2} / \mathrm{Ta}\right)= & 4.4 \times 10^{-8} \exp (-1620 / \mathrm{T}) \mathrm{m}^{2} / \mathrm{s} \\
\Phi\left(\mathrm{H}_{2} / \mathrm{Ta}\right)= & 5.8 \times 10^{-9} \\
& \quad \times \exp (2430 / \mathrm{T}) \mathrm{mol} / \mathrm{m} \cdot \mathrm{s} \cdot \mathrm{Pa}^{1 / 2}
\end{aligned}
$$

As with the other VB metals, caution is advisable in using this formula. Pressure and temperature ranges below $10 \mathrm{kPa}$ and above $350^{\circ} \mathrm{C}$ are appropriate to avoid nonlinearity and the two-phase region.

\section{Tungsten}

Three of the five tungsten permeation experi-

\begin{tabular}{|c|c|c|c|c|c|}
\hline $\begin{array}{c}\Phi_{0} \\
\left(10^{7} \mathrm{~mol} / \mathrm{m} \cdot \mathrm{s} \cdot \mathrm{Pa}^{1 / 2}\right)\end{array}$ & $\begin{array}{l}E_{\Phi} \\
\text { (K) }\end{array}$ & $\begin{array}{c}\text { Temperature range } \\
\text { (K) }\end{array}$ & $\begin{array}{l}\text { Pressure } \\
\text { (kPa) }\end{array}$ & Gas & Reference \\
\hline 0.0084 & 11,000 & $970-1150$ & 100 & $\mathbf{H}_{2}$ & Steigerwald (1963) \\
\hline 7.77 & 17,000 & $1600-2900$ & $10-100$ & $\mathrm{H}_{2}$ & Aitken et al. (1967) \\
\hline 7.6 & 15,900 & $1100-2400$ & $10^{-7}-13$ & $\mathrm{H}_{2}$ & Frauenfelder (1968) \\
\hline 6.0 & 16,600 & $1100-2400$ & Degas. expt & $\mathrm{H}_{2}$ & Frauenfelder (1969) \\
\hline 0.73 & 12,800 & $1000-1330$ & $0.1-30$ & $\mathrm{H}_{2}$ & Zakharov et al. (1973) \\
\hline
\end{tabular}
ments we have collected agree reasonably well, both in the preexponential and the activation energy (Table 7). The earliest (Steigerwald, 1963) and latest results (Zakharov et al., 1973) disagree the most. We favor Frauenfelder's work (1968, 1969) and that of Aitken et al. (1967) because they cover the widest temperature and pressure ranges and the results are similar. We choose Aitken

Table 7. Tungsten permeability data. 
et al.'s result as the "best" value below, because it falls between the two results of Frauenfelder:

$$
\begin{aligned}
\Phi\left(\mathrm{H}_{2} / \mathrm{W}\right)= & 7.8 \times 10^{-7} \\
& \times \exp (-17,000 / T) \mathrm{mol} / \mathrm{m} \cdot \mathrm{s} \cdot \mathrm{Pa}^{1 / 2} .
\end{aligned}
$$

\section{Vanadium}

As with niobium and tantalum, no direct measurements of hydrogen permeation through vanadium are available. We combine the solubility data of Veleckis and Edwards (1969),

$S\left(\mathrm{H}_{2} / \mathrm{V}\right)=0.138 \exp (3490 / T) \mathrm{mol} / \mathrm{m}^{3} \cdot \mathrm{Pa}^{1 / 2}$

with the average diffusivity values given by Völkl and Alefeld (1975),

$D\left(\mathrm{H}_{2} / \mathrm{V}\right)=2.9 \times 10^{-8}(-500 / T) \mathrm{m}^{2} / \mathrm{s}$,

and obtain a permeability:

$$
\begin{aligned}
\Phi\left(\mathrm{H}_{2} / \mathrm{V}\right)= & 4.0 \times 10^{-9} \\
& \times \exp (2990 / \mathrm{T}) \mathrm{mol} / \mathrm{m} \cdot \mathrm{s} \cdot \mathrm{Pa}^{1 / 2}
\end{aligned}
$$

This data is for the $\alpha$-phase $\mathrm{V} / \mathrm{H}_{2}$ system and should be used at pressures less than $1 \times 10^{4} \mathrm{~Pa}$ and greater than $300^{\circ} \mathrm{C}$.

\section{Zinc}

We could find no satisfactory work on zinc. Hendricks and colleagues (Hendricks and Ralston, 1929; Deming and Hendricks, 1923) used the membrane method between 600 and $700 \mathrm{~K}$. The temperature dependence is not clear. A permeation value at $650 \mathrm{~K}$ is:

$\Phi\left(\mathrm{H}_{2} / \mathrm{Zn}, 650 \mathrm{~K}\right)=5 \times 10^{-12} \mathrm{~mol} / \mathrm{m} \cdot \mathrm{s} \cdot \mathrm{Pa}^{1 / 2}$

We believe that this number is not reliable, though. Moon (1971) measured diffusion coefficients between 325 and $525 \mathrm{~K}$ and 5 and $100 \mathrm{kPa}$ hydrogen using gas-volumetric measurements. His results were:

$$
\begin{aligned}
D\left(\mathrm{H}_{2}, 99.99 \% \mathrm{Zn}\right) & =5.8 \times 10^{-7} \\
& \times \exp [(-7000 \pm 100) T] \mathrm{m}^{2} / \mathrm{s}
\end{aligned}
$$

and

$$
\begin{aligned}
& D\left(\mathrm{H}_{2}, 99.9 \% \mathrm{Zn}\right)=4.2 \times 10^{-7} \\
& \times \exp [(-11,100 \pm 100) T] \mathrm{m}^{2} / \mathrm{s} .
\end{aligned}
$$

\section{Other Pure Metals}

We did not find reports of hydrogen permeabilities for any of the following pure metals: antimony, arsenic, bismuth, boron, chromium, indium, iridium, manganese, osmium, rhenium, rhodium, ruthenium, tin, and thallium. Other metals were considered strong hydride formers.

Hydrogen solubilities in rhodium, ruthenium, and iridium were measured by McLellan and Oates (1973). Sieverts and Moritz measured the hydrogen solubility in manganese (1937).

\section{Iron and Nickel Alloys}

Because iron and nickel alloys are such an important class of materials, we reviewed them. The results are divided between stainless steels, other iron alloys such as Kovar and Ceramvar, and nickel-rich alloys (Tables 8 through 10 ).

Considering the wide variety of composition and microstructure, there is not a large difference in preexponentials or activation energies for the stainless alloys. The preexponential is in the $10^{-7}$ $\mathrm{mol} / \mathrm{m} \cdot \mathrm{s} \cdot \mathrm{Pa}^{1 / 2}$ range, and the activation energies are near $-8000 \mathrm{~K}$. The carbon steels as a group have a lower preexponential by about a factor of 10 and half the activation energy.

Ryabov, Salii, and Gel'd have measured permeabilities of several iron alloys with up to 10 wt\% germanium (Ryabov et al., 1976) and silicon (Salii ef al., 1973). The results were similar to those for iron. The silicon-containing alloys had decreasing preexponentials and increasing activation energies with increasing silicon content. With the germanium-containing alloys the preexponential increased; this was an unexpected result, since silicon and germanium have similar hydrogen permeabilities.

\section{Glasses}

Souers ct al. (1978) have reviewed the literature for hydrogen isotope permeability through 
Table 8. Stainless steel permeability data.

\begin{tabular}{|c|c|c|c|c|c|c|}
\hline $\begin{array}{l}\Phi_{0} \\
\left(10^{7} \mathrm{~mol} / \mathrm{m} \cdot \mathrm{s} \cdot \mathrm{Pa}^{1 / 2}\right)\end{array}$ & $\begin{array}{l}E_{\Phi} \\
(\mathrm{K})\end{array}$ & $\begin{array}{l}\text { Temperature range } \\
\text { (K) }\end{array}$ & $\begin{array}{l}\text { Pressure } \\
(\mathrm{kPa})\end{array}$ & Gas & Alloy & Reference \\
\hline 3.5 & 8200 & $775-1175$ & 100 & $\mathrm{H}_{2}$ & 303 & Gorman and Nardella (1962) \\
\hline 4.9 & 8600 & $825-1175$ & 100 & $\mathrm{H}_{2}$ & 304 & Gorman and Nardella (1962) \\
\hline 19.5 & 8660 & $375-575$ & 100 & $\mathrm{H}_{2}$ & 304 & $\begin{array}{l}\text { Chaney and Powell (1970), } \\
\text { Powell et al. (1970) }\end{array}$ \\
\hline 10.4 & 7700 & $350-900$ & $10-3000$ & $\mathrm{H}_{2}$ & 304 & Nelson and Stein (1973) \\
\hline 1.2 & 7100 & $425-875$ & $1-40$ & $\mathrm{H}_{2}$ & $309 S$ & Kass and Andrzejewski (1972) \\
\hline $1^{\mathrm{a}}$ & 8000 & $500-700$ & 100 & $\mathrm{D}_{2}$ & 3095 & Swansiger et al. (1974) \\
\hline 2.36 & 7650 & $350-1050$ & $10^{-3}-10^{-4}$ & $\mathrm{H}_{2}$ & 316 & Van Deventer and Maroni (1980) \\
\hline 3.1 & 7800 & $575-1075$ & $10-1000$ & $\mathrm{H}_{2}$ & 321 & Phillips and Dodge (1968) \\
\hline 0.853 & 7150 & $350-1050$ & $10^{-3}-10^{-4}$ & $\mathrm{H}_{2}$ & 321 & Van Deventer and Maroni (1980) \\
\hline 1.38 & 7932 & $370-700$ & $1-10$ & $\mathrm{~T}_{2}$ & $21-6-9$ & Swansiger (1976) \\
\hline
\end{tabular}

average of several results.

Table 9. Permeability data of other iron alloys.

\begin{tabular}{|c|c|c|c|c|c|c|}
\hline $\begin{array}{c}\Phi_{0} \\
\left(10^{7} \mathrm{~mol} / \mathrm{m} \cdot \mathrm{s} \cdot \mathrm{Pa}^{1 / 2}\right)\end{array}$ & $\begin{array}{c}E_{\Phi} \\
(\mathrm{K})\end{array}$ & $\begin{array}{l}\text { Temperature range } \\
\text { (K) }\end{array}$ & $\begin{array}{l}\text { Pressure } \\
(\mathrm{kPa})\end{array}$ & Gas & Alloy & Reference \\
\hline 3.15 & 8050 & $775-1225$ & 100 & $\mathrm{H}_{2}$ & Kovar & Gorman and Nardella (1962) \\
\hline 0.5 & 4300 & $600-900$ & 100 & $\mathrm{H}_{2}$ & Cold-drawn steel & Gorman and Nardella (1962) \\
\hline 1.11 & 7000 & $450-775$ & $10-100$ & $\mathrm{H}_{2}$ & Ceramvar & Perkins and Begeal (1972) \\
\hline 0.291 & 4800 & $350-900$ & $10-3,000$ & $\mathrm{H}_{2}$ & 4130 normal & Nelson and Stein (1973) \\
\hline 0.364 & 4340 & $350-900$ & $10-3,000$ & $\mathrm{H}_{2}$ & $\begin{array}{l}4130 \text { quenched/ } \\
\text { tempered }\end{array}$ & Nelson and Stein (1973) \\
\hline 3 to $1 \times 10^{-8}$ & $4250-5500$ & $600-1000$ & - & $\mathrm{H}_{2}$ & $\mathrm{Fe}, 0-10$ wt $\% \mathrm{Si}$ & Salii et al. (1973) \\
\hline 3 to $4 \times 10^{-8}$ & $4250-5000$ & $600-1000$ & - & $\mathrm{H}_{2}$ & $\mathrm{Fe}, 0-10 w t \% \mathrm{Ge}$ & Ryabov et al. (1976) \\
\hline
\end{tabular}

Table 10. Nickel alloy permeability data.

\begin{tabular}{|c|c|c|c|c|c|c|}
\hline $\begin{array}{c}\Phi_{0} \\
\left(10^{7} \mathrm{~mol} / \mathrm{m} \cdot \mathrm{s} \cdot \mathrm{Pa}^{1 / 2}\right)\end{array}$ & $\begin{array}{l}E_{\Phi} \\
(\mathrm{K})\end{array}$ & $\begin{array}{c}\text { Temperature range } \\
(\mathrm{K})\end{array}$ & $\begin{array}{l}\text { Pressure } \\
(\mathrm{kPa})\end{array}$ & Gas & Alloy & Reference \\
\hline 9.87 & 8400 & $775-1175$ & 100 & $\mathrm{H}_{2}$ & Inconel 600 & Gorman and Nardella (1962) \\
\hline 2.03 & 6440 & $725-1225$ & 100 & $\mathrm{H}_{2}$ & Monel 400 & Gorman and Nardella (1962) \\
\hline 2.12 & 7570 & $500-1000$ & $0.01-10$ & $\mathrm{H}_{2}$ & Haynes 188 & Van Deventer (1977) \\
\hline 2.56 & 7240 & $400-1000$ & $0.1-10$ & $\mathrm{H}_{2}$ & Inconel 625 & Van Deventer and Maroni (1980) \\
\hline 0.959 & 6780 & $400-1000$ & $0.1-10$ & $\mathrm{H}_{2}$ & Inconel 718 & Van Deventer and Maroni (1980) \\
\hline
\end{tabular}

glasses. Following the lead of Altemose (1961), they included the mole percent $\mathrm{M}$ of nonnetwork-forming or modifier oxides, e.g., $\mathrm{Na}_{2} \mathrm{O}$, $\mathrm{CaO}$, and $\mathrm{MgO}$, as variables affecting hydrogen permeability over a limited range in both the preexponential and activation energy. Doremus (1961) and Shelby (1972a, b) concluded that the permeability varies linearly as well as exponentially with temperature, giving the modified temperature-dependent equation:
$\Phi=\Phi_{0} T \exp \left(-E_{\Phi} / T\right)$.

The units of permeability through glasses and ceramics are $\mathrm{mol} / \mathrm{m} \cdot \mathrm{s} \cdot \mathrm{Pa}$, since several results have shown first-power dependence of permeability on pressure, unlike the metals. This is readily explained by the lack of hydrogen dissociation in the nonmetals, as compared with metals. The preexponential term $\Phi_{0}$ has in this form the unusual units $\mathrm{mol} / \mathrm{m} \cdot \mathrm{s} \cdot \mathrm{Pa} \cdot \mathrm{K}$. 
We repeat the summarized results of Souers et al. in Table 11 since they already represent a compilation of a wide body of data. Their results cover data that were taken over large ranges of temperature $(300-1500 \mathrm{~K})$ and pressure $(100 \mathrm{~Pa}$ $1 \mathrm{GPa}$ ). Because of the scatter in the available results, their best-fit equations are as accurate as can be expected.

Table 11. Glass permeability data.

\begin{tabular}{cccc}
$\begin{array}{c}\Phi_{0} \\
\left(10^{17} \mathrm{~mol} / \mathrm{m} \cdot \mathrm{s} \cdot \mathrm{Pa} \cdot \mathrm{K}\right)\end{array}$ & $\begin{array}{c}E_{\Phi} \\
(\mathrm{K})\end{array}$ & Gas & References \\
\hline $\begin{array}{c}\text { Silicate glasses } \\
{\left[3.4+\left(8 \times 10^{-4}\right) \mathrm{M}^{3}\right]^{\mathrm{a}}}\end{array}$ & $3600+165 \mathrm{M}$ & $\mathrm{H}_{2}, \mathrm{D}_{2}$ & Altemose (1961), Doremus (1961), Shelby (1972a, b) \\
& & & \\
Soda-lime glasses & 6700 & $\mathrm{H}_{2}, \mathrm{D}_{2}$ & Altemose (1961), Doremus (1961), Shelby (1972a, b) \\
9 & 5600 & $\mathrm{H}_{2}$ & Souers ef al. (1978) \\
20 & 5600 & $\mathrm{D}_{2}, \mathrm{DT}$ & Souers et al. (1978) \\
\hline
\end{tabular}

${ }^{a} M$ is mole percent of non-network-forming or modifier oxides. 


\section{References}

\section{Aluminum}

F. Boeschoten, W. van Egmond, and H. M. J. Kinderdijk, Appl. Sci. Res. B 8, 378 (1960).

C. N. Cochran, I. Electrochem. Soc. 108, 317 (1961).

Walter Eichenauer, Karl Hattenbach, and Alfred Pebler, Z. Metallkd. 52, 682 (1961).

Walter Eichenauer and Alfred Pebler, Z. Metallkd. 48, 373 (1957). This reference contains information on copper too.

H. Ihle, U. Kurz, and G. Stöcklin, Proc. Intern. Conf. Radiation Effects and Tritium Technology for Fusion Reactors, Gatlinburg, TN, 1975, National Technical Information Service, U.S. Dept. of Commerce, Springfield, VA, CONF-750989 (1976), p. IV-414.

\section{Beryllium}

R. M. Al'tovskiy, A. A. Eremin, L. F. Eremina, L. A. Izhvanor, V. N. Fadeyer, and M. I. Urazbayer, Russ. Mctall. (Eng. transl.) 3, 51 (1981).

J. P. Fidelle, L. R. Allemand, M. Rapin, and B. Hocheid, Colloque sur L'Hydrogène dans les Metaux, Valduc, 1967, p. 210. This reference also has information on cadmium.

P. M. S. Jones and R. Gibson, J. Nucl. Mater. 21, 353 (1967).

\section{Cadmium}

J. P. Fidelle, L. R. Allemand, M. Rapin, and B. Hocheid, Colloque sur L'Hydrogène dans les Metaux, Valduc, 1967 , p. 210 . This reference also has data on beryllium.

\section{Cobalt}

G. R. Caskey, Jr., R. G. Derrick, and M. R. Louthan, Jr., Scr. Metall. 8, 481 (1974).

\section{Copper and Copper Alloys}

D. R. Begeal, J. Vac. Sci. Technol. 15, 1146 (1978). This reference has information on gold too.

E. O. Braaten and. G. F. Clark, Proc. R. Soc. London, Ser. A 153, 504 (1936).

G. R. Caskey, Jr., and R. G. Derrick, Metall. Trans. 8A, 511 (1977).

G. R. Caskey, Jr., A. H. Dexter, M. L. Holzworth, M. R. Louthan, Jr., and R. G. Derrick, Corrosion (Houston) 32, 370 (1976).

Walter Eichenauer, Werner Löser, and Helmut Witte, Z. Metallkd. 56, 287 (1965). This reference contains information on nickel too.

Walter Eichenauer and Alfred Pebler, Z. Metallkd. 48, 373 (1957). This reference also contains data on aluminum.

J. K. Gorman and W. R. Nardella, Vacuum 12, 19 (1962). This reference also has data on nickel and on iron and nickel alloys.

W. G. Perkins and D. R. Begeal, Sandia Laboratories, Albuquerque, NM, Report SC-DC-714493 (1972). Data on iron alloys too may be found in this reference.

D. W. Rudd, D. W. Vose, and S. Johnson, J. Phys. Chem. 65, 1018 (1961).

C. J. Smithells and C. E. Ransley, Proc. R. Soc. London, Ser. A 150, 172 (1935). This reference contains information on molybdenum too. 


\section{Germanium}

A. Van Wieringen and N. Warmoltz, Physica (Utrecht) 22, 849 (1956).

\section{Gold}

D. R. Begeal, J. Vac. Sci. Technol. 15, 1146 (1978). Copper data may also be found in this reference.

G. R. Caskey, Jr., and R. G. Derrick, Scr. Metall. 10, 377 (1976).

\section{Iron}

O. D. Gonzalez, Trans. Metall. Soc. AIME 239, 929 (1967).

A. J. Kumnick and H. H. Johnson, Acta Metall. 25, 891 (1977).

A. J. Kumnick and H. H. Johnson, Metall. Trans. 6A, 1087 (1975).

M. R. Louthan, Jr., R. G. Derrick, J. A. Donovan, and G. R. Caskey, Jr., in Proc. Conf. Effect of Hydrogen on Behavior of Materials, Jackson Lake Lodge, Moran, WY, 1975, National Technical Information Service, U.S. Dept. of Commerce, Springfield, VA, CONF-750925-4 (1975).

Howard G. Nelson and James E. Stein, National Aeronautics and Space Administration, Washington, D.C., Technical Note NASA TN-D-7265 (1973).

N. R. Quick and H. H. Johnson, Acta Metall. 26, 903 (1978).

Rainer Wagner and Rudolf Sizmann, Z. Angew. Phys. 18, 193 (1975).

\section{Lead}

Horace G. Deming and B. Clifford Hendricks, J. Am. Chem. Soc. 45, 2857 (1923).

\section{Molybdenum}

G. R. Caskey, Jr., M. R. Louthan, Jr., and R. G. Derrick, J. Nucl. Mater. 55, 279 (1975).

W. T. Chandler and R. J. Walter, in Refractory Metal Alloys, I. Machlin, R. T. Begley, and E. D. Weisert, Eds. (Plenum, New York, 1968), 197-249.

R. Frauenfelder, I. Chem. Phys. 48, 3955 (1968). This reference contains information on tungsten too.

J. W. Gutherie, L. C. Beavis, D. R. Begeal, and W. G. Perkins, J. Nucl. Mater. 53, 313 (1974).

M. L. Hill, J. Met. 12, 725 (1960).

C. L. Huffine and J. M. Williams, Corrosion (Houston) 16, 430t (1960).

P. M. S. Jones, R. Gibson, and J. A. Evans, United Kingdom Atomic Energy Authority, Culham, U.K., AWRE 0-16166 (1966).

C. H. Smithells and C. E. Ransley, Proc. R. Soc. London, Ser. A 150, 172 (1935). This reference also has data on copper.

E. A. Steigerwald, National Aeronautics and Space Administration, Washington, D.C., CR 54004, ER-5623 (1963). This reference also contains information on tungsten.

A. P. Zakharov, V. M. Sharapov, and E. I. Evko, Sov. Mater. Sci. (Eng. transl.) 9, 149 (1973). Data on tungsten too may be found in this reference.

\section{Nickel}

Y. Ebisuzaki, W. J. Kass, and M. O'Keeffe, J. Chem. Phys. 46, 1378 (1967).

Walter Eichenauer, Werner Löser, and Helmut Witte, Z. Metallkd. 56, 287 (1965). This reference also has information on copper.

H. B. Gala, M. Kara, S. Sung, S. H. Chiang, and G. E. Klinzing, Am. Inst. Chem. Eng. J. 27, 159 (1981). 
J. K. Gorman and W. R. Nardella, Vacuum 12, 19 (1962). Copper data too may be found in this reference. W. R. Ham, J. Chem. Phys. 1, 476 (1933). This reference also has data on platinum.

M. R. Louthan, Jr., and R. G. Derrick, Scr. Metall. 10, 53 (1976).

M. R. Louthan, Jr., J. A. Donovan, and G. R. Caskey, Jr., Acta Metall. 23, 745 (1975).

Wayne M. Robertson, Z. Metallkd. 64, 436 (1973).

Tetsuo Tanabe, Yutaka Miyata, and Shosuke Imoto, Technology Reports of the Osaka University 27(1374), 389 (1977).

\section{Niobium}

S. A. Steward, J. Chem. Phys. 63, 975 (1975).

Ewald Veleckis and Russell K. Edwards, J. Phys. Chem. 73, 683 (1969). This reference also contains data on tantalum and vanadium.

J. Völkl and G. Alefeld, in Diffusion in Solids: Recent Developments, A. S. Nowick and J. J. Burton, Eds. (Academic Press, New York, 1975), 232-302. This reference also has information on tantalum and vanadium.

\section{Palladium}

Yu. A. Balovnev, Russ. J. Phys. Chem. 48, 409 (1974).

Stephen A. Koffler, John B. Hudson, and George S. Ansell, Trans. Mctall. Soc. AIME 245, 1735 (1969).

\section{Platinum}

Y. Ebisuzaki, W. J. Kass, and M. O'Keeffe, J. Chem. Phys. 49, 3329 (1968).

W. R. Ham, J. Chem. Phys. 1, 476 (1933). This reference contains information on nickel too.

Charles Harvie, John H. Weare, and Michael O'Keeffe, Geochim. Cosmochim. Acta 44, 899 (1980).

Hiroji Katsuta and Rex B. McLellan, J. Phys. Chem. Solids 40, 697 (1979).

Wei-ming Yei and Rex B. McLellan, "Thermodynamics of Dilute Platinum-Hydrogen Solid Solutions," J. Less-Common Mctals 64, 11 (1979).

\section{Silicon}

Torao Ichimiya and Akio Furuichi, Int. J. Appl. Radiat. Isot. 19, 573 (1968).

\section{Silver}

Hiroji Katsuta and R. B. McLellan, Scr. Mctall. 13, 65 (1979).

R. B. McLellan, J. Phys. Chem. Solids 34, 1137 (1973).

Y. I. Zvedin and Y. I. Belyakov, Sov. Mater. Sci. (Eng. transl.) 3, 255 (1967).

\section{Tantalum}

Ewald Veleckis and Russell K. Edwards, J. Phys. Chem. 73, 683 (1969). This reference also has information on niobium and vanadium.

J. Völkl and G. Alefeld, in Diffusion in Solids: Recent Developments, A. S. Nowick and J. J. Burton, Eds. (Academic Press, New York, 1975), 232-302. This reference also contains data on niobium and vanadium. 


\section{Tungsten}

E. A. Aitken, H. C. Brassfield, P. K. Conn, E. C. Duderstadt, and R. E. Fryxell, Trans. Metall. Soc. AIME 239, 1565 (1967).

R. Frauenfelder, J. Chem. Phys. 48, 3955 (1968). Molybdenum data too may be found in this reference.

R. Frauenfelder, J. Vac. Sci. Technol. 6, 388 (1969).

E. A. Steigerwald, National Aeronautics and Space Administration, Washington, D.C., CR 54004, ER-5623, (1963). This reference also contains information on molybdenum.

A. P. Zakharov, V. M. Sharapov, and E. I. Evko, Sov. Mater. Sci. (Eng. transl.) 9, 149 (1973). This reference also has data on molybdenum.

\section{Vanadium}

Ewald Veleckis and Russell K. Edwards, J. Phys. Chem. 73, 683 (1969). This reference also has information on niobium and tantalum.

J. Völkl and G. Alefeld, in Diffusion in Solids: Recent Developments, A. S. Nowick and J. J. Burton, Eds. (Academic Press, New York, 1975), 232-302. This reference also contains data on niobium and tantalum.

\section{Zinc}

Horace G. Deming and B. Clifford Hendricks, J. Am. Chem. Soc. 45, 2857 (1923).

B. Clifford Hendricks and Robert R. Ralston, J. Am. Chem. Soc. 51, 3278 (1929).

I. H. Moon, I: Korean Inst. Metals 9, 158 (1971).

\section{Other Pure Metals}

R. B. McLellan and W. A. Oates, Acta Metall. 21, 181 (1973).

A. Sieverts and H. Moritz, Z. Phys. Chem. (Leipzig) 180, 249 (1937).

\section{Iron and Nickel Alloys}

K. F. Chaney and G. W. Powell, Metall. Trans. 1A, 2356 (1970).

J. K. Gorman and W. R. Nardella, Vacuum 12, 19 (1962). This reference contains information on copper too. W. J. Kass and W. J. Andrzejewski, Sandia Laboratories, Albuquerque, NM, SC-DR-720136 (1972).

Howard G. Nelson and James E. Stein, National Aeronautics and Space Administration, Washington, D.C., Technical Note NASA TN D-7265 (1973).

W. G. Perkins and D. R. Begeal, Sandia Laboratories, Albuquerque, NM, SC-DC-714493 (1972). This reference also contains information on copper.

J. R. Phillips and B. F. Dodge, Am. Inst. Chem. Eng. J. 14, 392 (1968).

G. W. Powell, J. D. Braun, K. F. Chaney, and G. L. Downs, Corrosion (Houston) 26, 223 (1970).

R. A. Ryabov, V. I. Salii, P. V. Gal'd, and M. S. Tesler, Sov. Mater. Sci. (Eng. transl.) 12, 444 (1976).

V. I. Salii, R. A. Ryabov, and P. V. Gel'd, Phys. Met. Metallogr. (Eng. transl.) 35, 106 (1973).

W. A. Swansiger, in Proc. Intern. Conf. Radiation Effects and Tritium Technology for Fusion Reactors, Gatlinburg, TN, 1975, National Technical Information Service, U.S. Dept. of Commerce, Springfield, VA, CONF-750989 (1976), p. IV-401.

W. A. Swansiger, R. G. Musket, L. J. Weirick, and W. Bauer, J. Nucl. Mater. 53, 307 (1974).

E. H. Van Deventer, I. Nucl. Mater. 66, 325 (1977).

Erven H. Van Deventer and Victor A. Maroni, J. Nucl. Mater. 92, 103 (1980). 


\section{Glasses}

V. O. Altemose, J. Appl. Phys. 32, 1309 (1961).

R. H. Doremus, I. Chem. Phys. 34, 2186 (1961).

J. E. Shelby, I. Appl. Phys. 43, 3068 (1972a); J. Am. Ceram. Soc. 55, 195 (1972b).

P. C. Souers, I. Moen, R. O. Lindahl, and R. T. Tsugawa, J. Am. Ceram. Soc. 61, 42 (1978). 


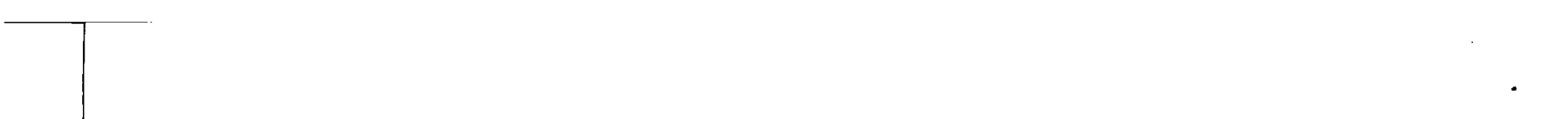




\section{Appendix}

Table A-1 lists the factors to convert commonly encountered permeation units to $\mathrm{mol} / \mathrm{m} \cdot \mathrm{s} \cdot \mathrm{Pa}^{1 / 2}$. Tables A-2 and A-3 give the selected "best" tritium and hydrogen permeabilities for quick reference.

Table A-1. Permeation rate conversion factors.

To convert to $\mathrm{mol} / \mathrm{m} \cdot \mathrm{s} \cdot \mathrm{Pa}^{1 / 2}$

\begin{tabular}{|c|c|}
\hline Multiply these units & by these factors: \\
\hline $\mathrm{cm}^{3}(\mathrm{STP})$ & \multirow[b]{2}{*}{$1.4015 \times 10^{-5}$} \\
\hline$\overline{\mathrm{cm} \cdot \mathrm{s} \cdot \mathrm{atm}^{1 / 2}}$ & \\
\hline $\mathrm{cm}^{3}(\mathrm{STP}) \cdot \mathrm{mm}$ & \multirow{2}{*}{$1.4015 \times 10^{-6}$} \\
\hline $\mathrm{cm}^{2} \cdot \mathrm{s} \cdot \mathrm{atm}^{1 / 2}$ & \\
\hline $\mathrm{cm}^{3}(\mathrm{STP}) \cdot \mathrm{mm}$ & \multirow[b]{2}{*}{$2.3358 \times 10^{-8}$} \\
\hline$\overline{\mathrm{cm}^{2} \cdot \min \cdot \mathrm{atm}^{1 / 2}}$ & \\
\hline $\mathrm{cm}^{3}(\mathrm{STP}) \cdot \mathrm{mm}$ & \multirow{2}{*}{$3.8932 \times 10^{-10}$} \\
\hline $\mathrm{cm}^{2} \cdot \mathrm{h} \cdot \mathrm{atm}^{1 / 2}$ & \\
\hline $\mathrm{cm}^{3}(\mathrm{STP})$ & \multirow{2}{*}{$3.8637 \times 10^{-4}$} \\
\hline$\overline{\mathrm{cm} \cdot \mathrm{s} \cdot(\text { torr })^{1 / 2}}$ & \\
\hline $\mathrm{cm}^{3}(\mathrm{STP}) \cdot \mathrm{mm}$ & \multirow[b]{2}{*}{$3.8637 \times 10^{-5}$} \\
\hline $\mathrm{cm}^{2} \cdot \mathrm{s}(\text { torr })^{1 / 2}$ & \\
\hline torr $\cdot$ liter & \multirow{2}{*}{$5.096 \times 10^{-4}$} \\
\hline $\mathrm{cm} \cdot \mathrm{s} \cdot(\text { torr })^{1 / 2}$ & \\
\hline$\mu \mathrm{m}(\mathrm{Hg}) \cdot$ liter & \multirow[b]{2}{*}{$1.8441 \times 10^{-8}$} \\
\hline $\mathrm{cm} \cdot \mathrm{s} \cdot \mathrm{atm}^{1 / 2}$ & \\
\hline
\end{tabular}


Table A-2. "Best" tritium permeability values for metals.

\begin{tabular}{|c|c|c|c|c|c|c|}
\hline Metal & $\begin{array}{c}\Phi_{0}^{\circ} \\
\left(\mathrm{mol} / \mathrm{m} \cdot \mathrm{s} \cdot \mathrm{Pa}^{1 / 2}\right)\end{array}$ & $\begin{array}{l}E_{\Phi} \\
(\mathrm{K})\end{array}$ & $\begin{array}{l}\text { Temperature } \\
\text { range } \\
\text { (K) }\end{array}$ & Pressure & Ref. gas & References \\
\hline Aluminum & $5.8 \times 10^{-5}$ & 14,800 & $420-520$ & $20 \mathrm{kPa}$ & $\mathrm{T}_{2}$ & Ihle et al. (1976) \\
\hline Beryllium & $5.8 \times 10^{-14}$ & 2,220 & $670-1170$ & Outgassing & $\mathrm{T}_{2}$ & Jones and Gibson (1967) \\
\hline Cobalt & $\begin{array}{l}5.1 \times 10^{-9}(\epsilon-\mathrm{Co}) \\
3.1 \times 10^{-8}(\alpha-\mathrm{Co})\end{array}$ & $\begin{array}{l}6,850 \\
7,750\end{array}$ & $\begin{array}{l}<670 \\
>670\end{array}$ & $\begin{array}{l}0.5 \mathrm{MPa} \\
0.5 \mathrm{MPa}\end{array}$ & $\begin{array}{l}\mathrm{D}_{2} \\
\mathrm{D}_{2}\end{array}$ & $\begin{array}{l}\text { Caskey et al. (1974) } \\
\text { Caskey et al. (1974) }\end{array}$ \\
\hline Copper & $4.9 \times 10^{-7}$ & 9,320 & $470-700$ & $0.13-130 \mathrm{kPa}$ & $\mathrm{H}_{2}$ & Begeal (1978) \\
\hline Germanium & $7 \times 10^{-6}$ & 24,000 & $1040-1200$ & $100 \mathrm{kPa}$ & $\mathrm{H}_{2}$ & Van Wieringen and Warmoltz (1956) \\
\hline Gold & $2.5 \times 10^{-6}$ & 14,800 & $500-900$ & $100-500 \mathrm{kPa}$ & $\mathrm{D}_{2}$ & Caskey and Derrick (1976) \\
\hline Iron & $2.4 \times 10^{-8}$ & 4,200 & $>375$ & $<10 \mathrm{MPa}$ & $\mathrm{H}_{2}$ & Gonzalez $(1967)^{b}$ \\
\hline Lead & - & - & - & - & - & Deming and Hendricks $(1923)^{c}$ \\
\hline Molybdenum & $1.3 \times 10^{-7}$ & 9,710 & $500-1700$ & - & $\mathrm{H}_{2}$ & Chandler and Walter (1968) \\
\hline Nickel & $1.54 \times 10^{-7}$ & 6,500 & $300-650$ & $0.1-30 \mathrm{MPa}$ & $T_{2}$ & Louthan and Derrick (1976) \\
\hline Niobium & $3.6 \times 10^{-9}$ & $-4,270$ & $>700$ & $<10 \mathrm{kPa}$ & $\mathrm{H}_{2}$ & $\begin{array}{l}\text { Völkl and Alefeld (1975), } \\
\text { Steward (1975) }\end{array}$ \\
\hline Palladium & $1.3 \times 10^{-7}$ & 1,885 & $300-709$ & 0.04-7 Pa & $\mathrm{H}_{2}$ & Koffler et al. (1969) \\
\hline Platinum & $6.9 \times 10^{-8}$ & 8,500 & $540-900$ & $70 \mathrm{kPa}$ & $\mathrm{H}_{2}$ & Ebisuzaki et al. (1968) \\
\hline Silicon & $8 \times 10^{-6}$ & 27,000 & $1240-1485$ & $100 \mathrm{kPa}$ & $\mathrm{H}_{2}$ & Van Wieringen and Warmoltz (1956) \\
\hline Tantalum & $3.3 \times 10^{-9}$ & $-2,430$ & $>650$ & $<10 \mathrm{kPa}$ & $\mathrm{H}_{2}$ & $\begin{array}{l}\text { Völkl and Alefeld (1975), } \\
\text { Veleckis and Edwards (1969) }\end{array}$ \\
\hline Tungsten & $4.5 \times 10^{-6}$ & 17,000 & $1100-2400$ & $10-100 \mathrm{kPa}$ & $\mathrm{H}_{2}$ & Aitken et al. (1967) \\
\hline Vanadium & $2.3 \times 10^{-9}$ & $-2,990$ & $>600$ & $<10 \mathrm{kPa}$ & $\mathrm{H}_{2}$ & $\begin{array}{l}\text { Völkl and Alefeld (1975), } \\
\text { Veleckis and Edwards (1969) }\end{array}$ \\
\hline
\end{tabular}

${ }^{a} \Phi_{0}\left(\mathrm{~T}_{2}\right)$ adjusted with $\sqrt{m_{\mathrm{H}_{2}}{ }^{m_{1}} \mathrm{D}_{2}} / \sqrt{m_{\mathrm{T}_{2}}}$ mass ratios.

b The value for $\mathrm{T}_{2}$ of Louthan et al. (1975) seems too high.

'Data unreliable. 
Table A-3. "Best" hydrogen permeability values for metals.

\begin{tabular}{|c|c|c|c|c|c|c|}
\hline Metal & $\begin{array}{c}\Phi_{0}^{\mathrm{a}} \\
\left(\mathrm{mol} / \mathrm{m} \cdot \mathrm{s} \cdot \mathrm{Pa}^{1 / 2}\right)\end{array}$ & $\begin{array}{c}E_{\Phi} \\
(\mathrm{K})\end{array}$ & $\begin{array}{c}\text { Temperature } \\
\text { range } \\
\text { (K) }\end{array}$ & Pressure & Ref. gas & References \\
\hline Aluminum & $5.8 \times 10^{-5}$ & 14,800 & $420-520$ & $20 \mathrm{kPa}$ & $\mathrm{T}_{2}$ & Ihle et al. (1976) \\
\hline Beryllium & $5.8 \times 10^{-14}$ & 2,220 & $670-1170$ & Outgassing & $\mathrm{T}_{2}$ & Jones and Gibson (1967) \\
\hline Cobalt & $\begin{array}{l}6.3 \times 10^{-9}(\epsilon-\mathrm{Co}) \\
3.8 \times 10^{-8}(\alpha-\mathrm{Co})\end{array}$ & $\begin{array}{l}6,850 \\
7,750\end{array}$ & $\begin{array}{l}<670 \\
>670\end{array}$ & $\begin{array}{l}0.5 \mathrm{MPa} \\
0.5 \mathrm{MPa}\end{array}$ & $\begin{array}{l}\mathrm{D}_{2} \\
\mathrm{D}_{2}\end{array}$ & $\begin{array}{l}\text { Caskey et al. (1974) } \\
\text { Caskey et al. }(1974)\end{array}$ \\
\hline Copper & $8.4 \times 10^{-7}$ & 9,320 & $470-700$ & $0.13-130 \mathrm{kPa}$ & $\mathrm{H}_{2}$ & Begeal (1978) \\
\hline Germanium & $1.2 \times 10^{-5}$ & 24,000 & $1040-1200$ & $100 \mathrm{kPa}$ & $\mathrm{H}_{2}$ & Van Wieringen and Warmoltz (1956) \\
\hline Gold & $3.1 \times 10^{-6}$ & 14,800 & $500-900$ & $100-500 \mathrm{kPa}$ & $\mathrm{D}_{2}$ & Caskey and Derrick (1976) \\
\hline Iron & $4.1 \times 10^{-8}$ & 4,200 & $>375$ & $<10 \mathrm{MPa}$ & $\mathrm{H}_{2}$ & Gonzalez (1967) \\
\hline Lead & - & - & - & - & - & Deming and Hendricks (1923) ${ }^{a}$ \\
\hline Molybdenum & $2.3 \times 10^{-7}$ & 9,710 & $500-1700$ & - & $\mathrm{H}_{2}$ & Chandler and Walter (1968) \\
\hline Nickel & $4 \times 10^{-7}$ & 6,600 & $300-775$ & $0.1-400 \mathrm{kPa}$ & $\mathrm{H}_{2}$ & $\begin{array}{l}\text { Ebisuzaki et al. (1967), Robertson } \\
\text { (1973), Louthan et al. (1975). }\end{array}$ \\
\hline Niobium & $6.3 \times 10^{-9}$ & $-4,270$ & $>700$ & $<10 \mathrm{kPa}$ & $\mathrm{H}_{2}$ & $\begin{array}{l}\text { Völkl and Alefeld (1975), } \\
\text { Steward (1975) }\end{array}$ \\
\hline Palladium & $2.20 \times 10^{-7}$ & 1,885 & $300-709$ & $0.04-7 \mathrm{~Pa}$ & $\mathrm{H}_{2}$ & Koffler et al. (1969) \\
\hline Platinum & $1.2 \times 10^{-7}$ & 8,500 & $540-900$ & $70 \mathrm{kPa}$ & $\mathrm{H}_{2}$ & Ebisuzaki et al. (1968) \\
\hline Silicon & $1.4 \times 10^{-5}$ & 27,000 & $1240-1485$ & $100 \mathrm{kPa}$ & $\mathrm{H}_{2}$ & Van Wieringen and Warmoltz (1956) \\
\hline Tantalum & $5.8 \times 10^{-9}$ & $-2,430$ & $>650$ & $<10 \mathrm{kPa}$ & $\mathrm{H}_{2}$ & $\begin{array}{l}\text { Völkl and Alefeld (1975), } \\
\text { Veleckis and Edwards (1969) }\end{array}$ \\
\hline Tungsten & $7.8 \times 10^{-7}$ & 17,000 & $1100-2400$ & $10-100 \mathrm{kPa}$ & $\mathrm{H}_{2}$ & Aitken et al. (1967) \\
\hline Vanadium & $4.0 \times 10^{-9}$ & $-2,990$ & $>600$ & $<10 \mathrm{kPa}$ & $\mathrm{H}_{2}$ & $\begin{array}{l}\text { Völkl and Alefeld (1975), } \\
\text { Veleckis and Edwards (1969) }\end{array}$ \\
\hline
\end{tabular}

a Data unreliable. 
